DOI: $10.19195 / 0137-1134.110 .10$

\author{
JOLANTA JABŁOŃSKA-BONCA
}

Akademia Leona Koźmińskiego w Warszawie

\title{
„EFEKT AUREOLI” I „EFEKT UCZESTNICTWA” A NIEZALEŻNOŚĆ PRAWNIKÓW-NAUKOWCÓW
}

Celem tekstu jest zasygnalizowanie potrzeby ciągłego badania problemów komplikujących warunki zewnętrzne zachowania niezależności prawników zajmujących się badaniami naukowymi. Przez niezależność badawczą rozumiem lojalność wobec norm metodologii i etyki badań naukowych. Wiedza, krytycyzm i niezależność sądów wyznaczają modelową pozycję każdego intelektualisty. Cenieni byli, są i zapewne będą zatem tacy naukowcy, którzy są kreatywni, przygotowani warsztatowo do prowadzenia badań, a także autonomiczni, zdolni do krytyki panującego status quo, dążący do prawdy bez względu na konsekwencje, będący — jeśli trzeba — „sumieniem” obywateli, zwłaszcza, gdy ci są niezadowoleni z władzy politycznej.

Jednak w XXI wieku o taką pozycję niezależności coraz trudniej. Wynika to stąd, że obecnie wielu naukowców-prawników poza nauką pełni jednocześnie inne ważne role społeczne i zawodowe.

Skoncentruję się na dwóch przykładach, sygnalizując, jak czynniki zewnętrzne utrudniają $\mathrm{w}$ dyskursie publicznym oraz $\mathrm{w}$ badaniach naukowych zachowanie niezależności i wikłają prawników-naukowców w ideologię i politykę. Tymi przykładowymi czynnikami są: a) aktywność prawników-naukowców w masowych mediach i konsekwencje tzw. efektu aureoli oraz b) „dwuzawodowość” i znaczenie „efektu uczestnictwa”.

Prawnicy-naukowcy pełnią często więcej niż jedną poważną rolę społeczną i zawodową. Przejawiają aktywność w dwóch, trzech, a niekiedy czterech rolach. Mogą to być przykładowo role: a) eksperta (radca prawny zatrudniony w określonej branży i specjalizujący się w wybranej problematyce) i naukowca; b) eksperta, naukowca i polityka albo dyplomaty; c) eksperta, dziennikarza, naukowca oraz prawnika-praktyka; d) prawnika-praktyka, naukowca, polityka i osoby po prostu znanej z mediów, w tym także blogera, czyli prywatnego komentatora życia politycznego, prawnego, gospodarczego i społecznego. 
Naukowcy wypowiadają się często o prawie w telewizji, radiu, popularnych czasopismach, na forach społecznościowych w Internecie, a także podejmują tematy pozaprawne: polityczne, ekonomiczne, obyczajowe itp. Występują publicznie z różnych pozycji: czasem jako eksperci, innym razem — jako „osoby znane z mediów" i dające wyraz prywatnej, indywidualnej ekspresji albo jako autorytety moralne uznane w społeczeństwie czy w jakieś grupie lub uznający się sami za takie autorytety, oczywiście także jako praktykujący prawnicy, prawnicy w rolach polityków, dyplomatów itp.

Jeśli przyznamy, że władzę w mediach ma ten, kto kontroluje dyskurs, prawnicy-naukowcy występujący w telewizji, w radiu, wypowiadający się w popularnych czasopismach o różnych profilach muszą poddawać się tej sile mediów ${ }^{1}$.

Problem polega na tym, że naukowcy prawie za każdym razem, bez względu na charakter i temat wypowiedzi (nawet jeśli jest bardzo odległa od ich naukowych kompetencji, np. profesor nauk prawnych opowiada o „kuchni politycznej”, sporcie albo o sztuce), używają w mediach swoich stopni naukowych i tytułu naukowego - niezależnie od tego, w jakiej roli występują. Stopnie i tytuły naukowe pozycjonują ich z jednej strony — bez względu na temat rozmowy - wysoko w formalnej hierarchii naukowej i z drugiej — subiektywnie — sytuują na ogół w opinii publicznej w podzbiorze: autorytet społeczny.

Tymczasem nie są przecież specjalistami w każdej z dziedzin, o której w mediach mówią lub piszą, tj. nie mają dorobku naukowego w wielu obszarach, po których się często poruszają w mediach. Nie są też uznawani przez środowisko naukowe za autorytety jednocześnie w każdej z tych sfer, a nawet jeśli wypowiadają się o prawie, to nie musi to być ich specjalizacja badawcza (o czym na ogół nie wiedzą odbiorcy i zadający pytania dziennikarze). Mimo to, świadomie albo nieświadomie, korzystają w mediach z pozytywnego „efektu aureoli”, mieszając pełnione role ${ }^{2}$. Ten ,efekt aureoli”, który jest formą zniekształcenia poznawczego, na pewno świadomie wykorzystują media, aby dzięki niemu uzyskać rezultat w postaci przekonania opinii publicznej do jakiejś sprawy z wykorzystaniem ukrytej manipulacji autorytetem naukowym.

Jeśli ktoś jest uznanym za autorytet profesorem nauk prawnych i ten fakt jest odbierany przez opinię publiczną pozytywnie, kojarzy się bowiem z doświadczeniem i wiedzą, z wysokim profesjonalizmem, przypisanie tych właściwości wpływa na skłonność do automatycznego przyznania mu również innych cech,

${ }^{1}$ Inaczej jest w blogosferze, na portalach społecznościowych, o czym niżej; choć również w Internecie są różne narzędzia kontroli informacji, np. rewizorzy wpływający na treść wpisów w Wikipedii. O tym, co się znajdzie na stronach Wikipedii, decyduje wąska grupa rewizorów. Rewizor może zmienić, zablokować lub usunąć każdy wpis. Por. W. Biedroń, Nowe narzędzie manipulacji, ,wSIECI” 5, 1.12.2016, s. 40-42.

2 Efekt aureoli - zniekształcenie poznawcze, tendencja do automatycznego, pozytywnego lub negatywnego przypisywania ważnej własności obiektowi na podstawie pozytywnego lub negatywnego wrażenia. „Aureola” może więc być pozytywna lub negatywna. 
które są zgodne z pozytywnym znakiem emocjonalnym pierwszego przypisanego atrybutu, a których wcale ta osoba nie musi albo nawet nie może mieć. Innymi słowy, jest wysoce prawdopodobne, że odbiorca komunikatu uzna, że taki prawnik na pewno też zna się np. na politycznej grze, na terroryzmie, na życiu gospodarczym w Chinach czy meandrach psychologii.

Trudności oddzielenia przez przeciętnego odbiorcę komunikatu profesjonalisty (w określonej dziedzinie) od ignoranta (w jakieś innej sferze) pogłębia fakt, że jednocześnie w sferze publicznej, w mediach, zauważalne jest wyraźnie zacieranie się granicy między autorytetem a każdą osobą popularną. „Politycy, intelektualiści, poważni komentatorzy, pisarze i naukowcy zaczęli jako celebryci konkurować z gwiazdami szoł-biznesu ${ }^{3 "}$. W tej ostatniej grupie celebrytów bywają także prawnicy. Przypomnijmy sobie wobec tego, jakimi prawami komunikacji rządzą się masowe media.

Po pierwsze, liczne badania socjologów i psychologów wykazały bezspornie, że pośrednictwo mediów w komunikacji — także komunikacji naukowca z otoczeniem - ogranicza sceptycyzm i krytycyzm w myśleniu adresatów wypowie$\mathrm{dzi}^{4}$. Naukowiec nie adresuje swoich wypowiedzi w mediach na ogół do innych profesjonalistów, lecz formułuje twierdzenia w sposób dostosowany do nieprofesjonalnego odbiorcy. Wie, że nawiązanie kontaktu z masowym odbiorcą przy wykorzystaniu środków masowej komunikacji wymaga formy prostej i obrazowej, przedstawiania wiadomości z pominięciem odsłaniania procedur poznawczych, których użyto do ich konstrukcji. Chodzi raczej o przekonanie opinii publicznej, a nie o kształtowanie rozwiniętych strategii poznawczych u odbiorców i zachęcenie ich do intersubiektywnej kontroli metodologii prowadzonych badań.

Po drugie, w masowych mediach używa się języka i stylu wypowiedzi innego niż w nauce, dąży się bowiem do innego celu, a więc metody, jakie się przy tym stosuje, można oceniać tylko na podstawie tego, w jakim stopniu przyczyniają się one do spełniania tych funkcji. Wartość wypowiedzi zależy od tego, do czego ma ona służyć. Język popularyzacji nauki czy język ideologii nie jest tożsamy $\mathrm{z}$ językiem nauki. Wypowiedzi w tekstach naukowych pełnią głównie funkcję referencyjną (opisową). W mediach wykorzystywane są szeroko również inne zadania przekazu werbalnego, takie jak funkcje: ekspresyjna, estetyczna, perswazyjna, fatyczna, performatywna, manipulacyjna ${ }^{5}$.

Po trzecie, zalew informacji w mediach i brak indywidualnej możliwości konfrontacji ich treści z rzeczywistością powodują, że uzasadnienia i wyjaśnienia medialne są skrótowe, uproszczone, nie muszą i na ogół nie mogą spełniać kryteriów intersubiektywnej kontrolowalności. Zbiorowość porozumiewa się w mediach — paradoksalnie — raczej bez dyskursu, poza prawdą i fałszem, bez potrzeby

3 J. Żakowski, Polityk, celebryta, banita, „Polityka” 2010, nr 4, s. 17.

${ }^{4}$ Por. szerzej np. J. Jabłońska-Bonca, Prawo w kręgu mitów, Gdańsk 1996; J. Jabłońska-Bonca, K. Zeidler, Prawnik a sztuka retoryki i negocjacji, Warszawa 2016, s. $71 \mathrm{n}$.

5 J. Jabłońska-Bonca, K. Zeidler, op. cit., s. 57. 
stosowania określonych strategii poznawczych, bez potrzeby weryfikacji sądów ${ }^{6}$. Naukowcy o tym wiedzą i mogą świadomie wykorzystywać tę właściwość kultury masowej do celów ideologicznych, do lansowania określonych sądów i opinii lub sami być wykorzystywani do promowania określonych przez media tez. Bez względu na to, jak wiadomości zawarte w przekazie werbalnym mają się do faktów, ile zawierają ładunku emocjonalnego, odnoszą skutek już choćby dlatego, że mówi o nich naukowy autorytet, a prawie nikt, kto jest odbiorcą komunikatu, nie ma czasu, a także warsztatu metodologicznego, aby samodzielnie dociekać prawdy i sprawdzać wygłaszane sądy. Ta pułapka mediów wciąga jednostki i całe zbiorowości, które łatwo ulegają złudzeniu, że skoro w 100 sekund można coś wyjaśnić w mediach, to wiedza o prawie nie jest zawiła, a aby ją posiąść w stopniu dostatecznym, nie musimy dokonywać żadnych szczególnych zabiegów, żmudne badania i wieloletnie studia są zbędne.

Po czwarte, do XX wieku prawnicy zajmujący się nauką wymieniali profesjonalne poglądy głównie we własnym autonomicznym środowisku, czyli między sobą, na konferencjach, sympozjach, w czasopismach, przez fachowe książki oraz trafiali w „wewnętrznym naukowym obiegu profesjonalnym” do prawników-praktyków, współkształtując orzecznictwo sądowe. Korzystali w komunikacji między sobą ze specjalnego kodu porozumiewania, który M. Marody nazywa „kodem wypracowanym" ". Wiedza uzyskana i komunikowana w świecie prawników z wykorzystaniem kodu wypracowanego to wiedza profesjonalna o dużym stopniu formalizacji procesu uczenia, charakteryzująca się doprecyzowanymi metodologiami legitymującymi włączanie określonych treści do jej zasobów oraz uporządkowaną wewnętrzną strukturą.

Jednak dzięki nowym technologiom, telewizji, Internetowi doktryna prawnicza w XXI wieku opuściła tradycyjny, hermetyczny świat zamkniętej komunikacji naukowej i wkroczyła szeroko do mediów, zdobywając przez wiele kanałów bezprecedensowe możliwości dialogu i oddziaływania na opinię publiczną. W tych nowych okolicznościach oczywiste okazało się, że nie sposób utrzymać zasady profesjonalnej komunikacji i trzeba zmienić kod porozumiewania na kod prosty. Z psychologicznego punktu widzenia niezakłócony i skuteczny przekaz jest możliwy, jeśli nawiążemy kontakt z rozmówcą, tj. będziemy posługiwali się znakami znaczącymi dla odbiorcy to samo, co dla nas.

Kiedy drugiego człowieka chce się przekonać do własnych poglądów — pisał św. Tomasz z Akwinu - trzeba podejść tam, gdzie on stoi, wziąć go za rękę i poprowadzić. Nie wolno traktować go jak statysty w teatrze i kazać mu podejść. Trzeba zacząć z tego punktu, w którym on się znajduje. To jedyny sposób ruszenia go z miejsca ${ }^{8}$.

Po piąte, media mają inne podstawowe zadania niż komunikujący coś otoczeniu naukowcy — wprawdzie jedni i drudzy przekazując dane, redukują napięcia

${ }^{6}$ M. Czerwiński, Magia, mit, fikcja, Warszawa 1973, s. 10.

7 Por. szerzej: M. Marody, Technologie intelektu, Warszawa 1987.

${ }^{8}$ Cyt. za: A.L. McGinnis, Sztuka motywacji, czyli jak wydobyć z ludzi to, co w nich najlepsze, przeł. W. Wojciechowski, Warszawa 1992, s. 33. 
informacyjne, zaspokajając naturalne indywidualne i zbiorowe pragnienie pewności, ale robią to w inny sposób i często w innym celu. Media absorbują niepewność informacyjną i nawet jeśli mamy niepełne dane, wykonują swoje zadania, porządkując obraz wycinka rzeczywistości w taki sposób, że powstaje aprioryczna synteza uznana kognitywnie, wolicjonalnie albo mentalnie, co do zasady nieprzewidująca żadnej procedury dostępnej odbiorcy, pomyślanej jako sposób weryfikacji wyrażonego sądu'. W nauce również stawia się hipotezy wyjaśniające na podstawie niepełnych danych, ale są to na ogół prowizoryczne ustalenia, niezamykające dalszych etapów procesu poznania; a za niedopuszczalne uznaje się przyjmowanie tez na podstawie wiary $\mathrm{w}$ jakiś sąd, a nie na podstawie intersubiektywnie kontrolowalnej wiedzy. Jednak w mediach „zdroworozsądkowa chęć zrozumienia i panowania nad sytuacją potrafi zadowolić się czymkolwiek" - twierdzi T. Hołówka ${ }^{10}$. Zdroworozsądkowe uznawanie zdań za prawdziwe przyjmuje wszystko, co czyni świat ,zadomowionym” i posłusznym ,prawom” w które odbiorca, szukając pewności, jest skłonny uwierzyć.

Naukowcy, decydując się na publiczne wystąpienia i dyskusje, wiedzą o tym. Przyjmują panujące w masowych mediach reguły gry i reguły wygrywania, m.in. dostosowują się do specjalnego kanonu zachowań retorycznych i erystycznych. Dzięki mediom wytworzyła się nawet nowa, specjalna klasa profesjonalnych „naukowo-medialnych" prawników, którzy wyspecjalizowali się w komunikacji tego typu. Systematycznie komentują oni fakty, i to nie tylko prawne.

Prawnicy „naukowo-medialni” występują publicznie i oficjalnie nadal w roli naukowców, ale wraz ze wzrostem popularności, za namową ludzi mediów, poszerzają przedmiotowo swój wachlarz wypowiedzi na coraz rozleglejsze tematy. Jeśli mają stać się osobowościami mediów, zostać zauważeni podczas każdej wypowiedzi i zapamiętany ma być ich głos, wiedzą, że nie mogą komunikować się z opinią publiczną z wykorzystaniem wypracowanego kodu, czyli profesjonalnego języka prawniczego. Muszą zmienić kod komunikacyjny, jeśli chcą budować przez media swoją markę osobistą i skutecznie docierać do opinii publicznej. Język decyduje o sposobie postrzegania rzeczywistości przez odbiorów. Media kontrolują więc również treści, które mogą się pojawiać w dyskursie medialnym. Kontrolują też momenty i miejsca pojawiania się naukowców, wszystkie „wejścia” naukowców do ich systemu komunikacji ${ }^{11}$. Kontekst sytuacyjny, czas i miejsce, w którym pojawia się wypowiedź, mają duży wpływ na odbiór komunikatu ${ }^{12}$.

$\mathrm{W}$ tradycyjnym, pozamedialnym, autonomicznym dyskursie naukowym „wejścia do wewnętrznego systemu” prawniczej komunikacji naukowej kontro-

9 J. Jabłońska-Bonca, Prawo w kręgu mitów, Gdańsk 1995.

10 T. Hołówka, Myślenie potoczne, heterogeniczność zdrowego rozsądku, Warszawa 1986.

11 Inną sytuację stwarza Internet - o czym niżej.

12 Por. odbiór komunikatu prawnika wypowiadającego się na ulicy na tle tłumu krzyczących demonstrantów, przeciwników władzy; w salonie, w gronie politycznych zwolenników władzy, na tle księgozbioru w bibliotece. 
lowały i kontrolują same autorytety prawnicze, które decydowały i decydują, kto może, a kto nie może wstąpić na naukowe „pole władzy”. ${ }^{13}$ Jeśli można teraz równolegle, szybko i często komunikować się oraz komunikować coś opinii publicznej poza tym „wewnętrznym obiegiem”, czyli przez nowe media, należy uznać, że „władza” nad nauką prawa de facto się rozszczepiła i nowe media również dysponują spektakularną ,władzą dostępu” i mogą pomagać w kreowaniu nowych autorytetów prawniczych. Kontrolują treści, które w dyskursie popularnym o prawie mogą się szybko pojawiać, być ożywiane, podgrzewane emocjonalnie, mają też moc — tak jak dawniej miało samo środowisko i tradycyjne środki komunikacji - tworzenia sfer tabu, wykluczając pewne tematy z dyskursu.

Nie ulega wątpliwości, że media masowe są uznawane za instytucje o obliczu politycznym, mają wyraźne profile ideologiczne i żyją głównie właśnie z polityki, jako IV władza, a nie z czystej, neutralnej, służby publicznej. To zaciemnia krystaliczny obraz „służby popularyzatorskiej” czy eksperckiej „niezależnych autorytetów prawniczych" zajmujących się badaniami naukowymi. Jeśli prawnik-naukowiec często komentuje wydarzenia w wybranych, wyprofilowanych politycznie mediach i nie ma kontroli nad kontekstami, w jakich te wypowiedzi się pojawiają, traci na ogół w odbiorze społecznym walor bycia neutralnym naukowcem. „Naukowo-medialni” prawnicy występują więc - często zapewne nie w pełni świadomie - w pozanaukowych, ideologicznych rolach publicznych.

Zapewne wiele z tych wystąpień można zakwalifikować do neutralnego politycznie obszaru popularyzacji problematyki nauk prawnych. Jednak częściej — ze względu na specyfikę formy komunikacji z opinią publiczną, kontekst, czas, formę i treść wypowiedzi oraz funkcje mediów - opinie eksperckie mają wyraźnie dostrzegalne tło ideologiczne.

Każdy prawnik powinien wiedzieć, że dominującą rolę, w ramach tzw. demokracji medialnej, odgrywa kreowanie i reżyserowanie przekazu płynącego do opinii publicznej i odbywa się to z wykorzystaniem stereotypów, mitów, uprzedzeń, przekłamań oraz całego arsenału werbalnych i pozawerbalnych chwytów erystycznych ${ }^{14}$.

Każdy prawnik powinien wiedzieć również, że chwyty erystyczne w mediach są efektowniejsze i często skuteczniejsze niż retoryczne argumenty ad rem, ponieważ sukces w przekonywaniu jest w tym wypadku efektem wykorzystania emocji, a te, bez wątpienia, działają na opinię publiczną silniej niż intelekt. Ponadto w systemach rozchwianych aksjologicznie niepewność emocjonalna wzmaga zdolność adresatów komunikatów do ulegania sugestiom. Ale każdy naukowiec też wie, że w nauce taki sposób argumentacji jest niedopuszczalny.

13 W tym tekście pomijam rolę władzy politycznej w kreowaniu samych naukowych autorytetów i naukowego „pola władzy”; na ten temat zob. J. Jabłońska-Bonca, Auctoritas non veritas facit legem? Z problematyki autorytetów prawniczych, [w:] Profesjonalna kultura prawnicza, red. M. Pichlak, Wrocław 2012, s. 135-153.

14 Szerzej zob. J. Jabłońska-Bonca, K. Zeidler, op. cit. 
Problem w tym, że prawnik-naukowiec, wiedząc o tym, świadomie wypowiada się emocjonalnie w mediach na ogół jako ekspert w sprawach o bardzo dużym znaczeniu społecznym i politycznym. Mówi lub pisze o prawie oraz o jego działaniu w konkretnym systemie politycznym, gospodarczym i społecznym, a także o wielu innych gorących aksjologicznie sprawach, a więc ranga ewentualnego wywieranego wpływu na opinię publiczną, a co za tym idzie wpływu na poziom legitymizacji władzy w ogóle albo legitymizacji konkretnych decyzji politycznych, jest wysoka, zupełnie inna niż naukowca występującego w mediach i zajmującego się zoologią, lingwistyką stosowaną czy paleontologią.

Prawnicy-naukowcy są świadomi, że współpracują politycznie z IV władzą, a nie z neutralną platformą ujawniania tez eksperckich, i że ma to określone konsekwencje dla sposobu odbioru ich komunikatów, dla tego, jakie tematy są podejmowane, dla czasu, miejsca i okoliczności, a także dla nich samych i ich środowiska zawodowego.

Na przykład zapewne wiedzą, że są proszeni o komentarz i występują publicznie tylko wtedy, kiedy medium umieści konkretny problem w tzw. agendzie tematów, a więc to media nadają zagadnieniu odpowiednią rangę. Nie tylko wygłaszają wówczas swoje sądy, ale i ich wypowiedzi pełnią dodatkowe funkcje, np. pomagają mediom ,wprowadzać” określone tematy do opinii publicznej, wzmocnić ich rangę, ożywiać je, np. podsycając emocje polityczne. Ale są też świadomi, że mogą być zaproszeni i wykorzystani odwrotnie: do „wyrzucania” ze świadomości opinii publicznej jednych informacji i zastępowania ich innymi w celu tzw. skrócenia horyzontu pamięci historycznej. Mogą więc pomagać w tym, aby określone tematy i spory,, żyły” politycznie, ekonomicznie, społecznie lub prawnie krótko albo dłużej. Nie ma wątpliwości, że w tych wypadkach uczestniczą w realizacji celów propagandowo-ideologicznych.

„Wprowadzanie” przez media i przez prawnicze autorytety naukowe określonych problemów lub ich pomijanie w tzw. agendzie tematów może więc służyć strategii tworzenia tematów tabu w polityce, w gospodarce, w życiu społecznym oraz odwrotnie — ożywianiu zainteresowania opinii publicznej konkretnym zagadnieniem, wzmacnianiu albo osłabianiu ogólnej legitymizacji władzy politycznej albo poparciu konkretnej decyzji. To przecież nie prawnicy-naukowcy, ale media same decydują, o czym się publicznie dyskutuje, a co przemilcza ${ }^{15}$. „Potęga środków przekazu jest taka wielka, że wpływają nie tylko na to, jak ludzie myślą, ale także o czym myślą. Dla wielu rzeczywistością jest to, co środki przekazu

15 Por. Ł. Bardziński, Postpolityka czy polityka medialna?, http://www.psz.pl/tekst-21320/ Lukasz-Bardzinski-Postpolityka-czy-polityka-medialna; P. Kusiak, Postpolityka. W poszukiwaniu istoty zjawiska, „Colloquium” 3, 2011, s. 171; P. Żuk, Wstęp. Demokracja spektaklu, czyli przymus przez uwodzenie, [w:] Media i władza, red. P. Żuk, Warszawa 2006, s. 10. 
uznają za rzeczywiste. Wszystko, czemu nie poświęcają uwagi, wydaje się pozbawione znaczenia"16.

Prawnicy-naukowcy są na ogół świadomi, w jakim medium, w jakim czasie i okolicznościach zdecydowali się wystąpić, jaki jest profil polityczny, ideologiczny stacji telewizyjnej, czasopisma czy portalu internetowego, i są świadomi, że ma to wpływ na postrzeganie ich postawy.

Nieco więcej autonomicznej władzy nad własnym przekazem adresowanym do szerokiego grona adresatów mają naukowcy w Internecie, np. jeśli prywatnie prowadzą blogi. Wówczas sami wyznaczają sobie agendy tematów i czas wystąpień. Mogą kontaktować się z odbiorcami na własnych warunkach.

Ale także Internet zastawia różne pułapki na tradycyjnie elitarny świat prawników, tworząc nową, egalitarną przestrzeń dyskursu, a do takiej demokratycznej sytuacji prawnicy nie są przyzwyczajeni. Dotąd prawo wygłaszania autorytatywnych opinii mieli ci, których dopuszczało samo środowisko prawnicze (liczą się opinie uznanych autorytetów); na ,pole władzy prawniczej” dopuszczani byli nieliczni, spełnienie kryteriów było bardzo trudne. Tymczasem Internet systematycznie kruszy stabilność wewnętrznych porządków w środowiskach naukowych i kwestionuje ustaloną hierarchię autorytetów ${ }^{17}$. Wirtualne środowisko, media społecznościowe, fora sieciowe, blogi i inne środki komunikacji zaoferowały, zwłaszcza młodszym prawnikom, taką nową płaszczyznę kontaktów, która umożliwiła nieograniczone szerzenie informacji i ocen także niezgodnych ze ,środowiskowym" uznaniem, w tym rozrywających granice ustalone przez ,zgodne opinie autorytetów"18.

Na blogach, na portalach społecznościowych ukazują się liczne teksty, bardzo krytyczne wobec tez i postulatów uznanych prawników i wobec nich samych. Są to teksty na ogół anonimowe. Część dyskursu prawniczego albo z prawnikami trwa więc obecnie w blogosferze. Debata, rządząc się innymi prawami, przesuwa się też z mainstreamowych mediów na Facebooka i Twittera.

Powstaje w ten sposób nowa, alternatywna przestrzeń dyskursu publicznego, dostępna także m.in. dla prawników ,niszowych”, niemających dotąd wielkich szans na publikacje i wyrażanie opinii w mainstreamowych czasopismach prawniczych oraz w kluczowych politycznie dla władzy i opozycji mediach. Przestrzeń ta nie jest neutralna politycznie i ma znaczenie dla prawniczego, kulturowego centrum $^{19}$.

16 Instrukcja Aetatis novae Papieskiej Rady do Spraw Środków Społecznego Przekazu, cyt. za: K. Czuba, Media i władza, Warszawa 2004, s. 92.

$17 \mathrm{~W}$ tekście pomijam wpływ władzy politycznej na stabilność albo rozpad środowisk, jest to temat na osobną pracę.

18 Powstają też nowe formy cenzury, por. np. przypis 1 .

19 Przykładowo, po ogłoszeniu w 2010 roku kandydatur na Prezesa TK ukazały się w Internecie setki komentarzy na temat obojga kandydatów. Czy to, co tam wówczas pisano, jest bez znaczenia w dłuższej perspektywie dla autorytetu tych osób i dla autorytetu prawa? Gdyby nie było Internetu, 
Warto podjąć szersze badania nad społecznym charakterem, znaczeniem i funkcjami wypowiedzi naukowców-prawników w nowych mediach społecznościowych. Czy rację ma P. Pamernantsev, że

zamiast torować drogę nowej epoce mówienia prawdy, era informacji umożliwia kłamstwom rozprzestrzenienie się na zasadzie „cyfrowej pożogi” [...] Media społecznościowe prowadzą nas do podobnie myślących ludzi, karmiących nas wyłącznie tym, co poprawia nasze samopoczucie, niezależnie od tego, czy coś pokrywa się z prawdą? ${ }^{20}$

Oto przykładowe wypowiedzi profesorów nauk prawnych w znanych czasopismach, na blogu, na stronie internetowej wysoko nakładowego dziennika, ilustrujące zasygnalizowane problemy:

— „Tym samym wkroczył z buciorami w kompetencje władzy sądowniczej, do czego nie miał żadnych uprawnień. $Z$ tego powodu prezydent może być postrzegany jako funkcjonariusz PiS"21.

— „Mamy już dyktaturę? Mamy demokrację Kiepskich [...] Jacyś zakompleksieni ludzie o przegranych życiorysach dostali narzędzie do ręki, którym się posługują jak cepem. [...] Już widać, że część prokuratorów jest gotowa porzucić rolę prokuratora Rzeczypospolitej dla roli oficera politycznego".

— „W marcu rozmawiam z jednym z najwybitniejszych polityków europejskich, Giuliano Amato. [...] Amato słucha [...] ze stoickim spokojem, ale nie wytrzymuje dopiero, gdy mu mówię, że rząd już zapowiedział, że wyroku nie opublikuje. »U nas w takiej sytuacji wkroczyłby Prezydent!«. Dopiero muszę wytłumaczyć mojemu rozmówcy, że w Polsce nie ma obecnie prezydenta. Jest Andrzej Duda. Ta rozmowa przypomniała mi się dziś, w pierwszą rocznicę objęcia urzędu przez Andrzeja Dudę. Przy tej okazji wszystko już zostało powiedziane o tym, jakim nieszczęściem dla Polski jest fakt, że ten urząd pełniony jest przez człowieka lękliwego, bez charakteru i inteligencji. Działa jak zdyscyplinowany uczestnik zorganizowanej grupy przestępczej, żyrujący wszystkie najgorsze rozkazy swego zwierzchnika".

— „Jestem z gruntu przeciwna Unii. Czekam i modlę się, żeby to się po prostu samo rozwaliło".

Każdy z wypowiadających te słowa jest podpisany i jest znanym profesorem nauk prawnych. Oczywiście nie są to tezy naukowe. Są to polityczne wypowiedzi ocenne (np. „nieszczęściem dla Polski”), prezentacje osobistych przeświadczeń

taka sytuacja publicznego komentowania przez setki osób cech osobowych i ocen życia kandydatów, niewątpliwych autorytetów prawniczych, byłaby niemożliwa.

20 P. Semka, Postprawda w wolność słowa, „Do Rzeczy” 2016, nr 49, 5-11.12.2016.

21 W kolejności cytaty z wypowiedzi: profesora pracującego na wyższej uczelni w Polsce, profesora piastującego ważną funkcję w wymiarze sprawiedliwości, profesora pracującego na wyższej uczelni w Polsce oraz od lat zagranicą, profesora uczelnianego — jednocześnie znanego polityka. Nie podaję nazwisk, ponieważ nie chodzi o te osoby, ale o problem. Kolejno są to wypowiedzi: w czasopiśmie o wyraźnym profilu politycznym, w wysoko nakładowym tygodniku, na własnym blogu, szeroko czytanym, na stronie internetowej wysoko nakładowego dziennika. Podkreślenia — J.J.-B. 
(,jestem z gruntu przeciwna”), niektóre też są hipotezami zdecydowanie spoza zakresu nauk prawnych (np. hipoteza z zakresu psychologii, jaką stawia profesor filozofii prawa: „,złowiek lękliwy, bez charakteru i inteligencji”). Zawierają bogaty zestaw środków erystycznych, są to m.in. wyraziste metafory („demokracja Kiepskich”), insynuacje (np. „część prokuratorów...”), ostre ataki ad personam („człowiek lękliwy, bez charakteru i inteligencji”).

Przyjrzyjmy się bliżej ich stylowi — dla przykładu metaforom i zadaniom, jakie pełnią one w zaprezentowanych fragmentach pozanaukowych tekstów naukowców.

Metafory są efektownym i efektywnym środkiem erystycznym (np. „wkroczył z buciorami”, „demokracja Kiepskich”). Każdy naukowiec wie, że powodują wysoce wybiórcze przeniesienie znanych skojarzeń danego słowa i służą wywoływaniu określonych emocji. Skojarzenia te następnie funkcjonują jako filtry, poprzez które spoglądamy na poznawane zjawisko, niektóre z jego cech są pomijane, inne zostają uwydatnione. Metafora kreuje nowy układ powiązań poprzez zestawienie dwóch układów odniesienia, które odbiorca musi brać jednocześnie pod uwagę. Odbywa się „,wymiana międzykontekstowa” (np. kontekst Kiepskich i demokracji, kontekst „wkraczania buciorów”, nie są to wszakże lakierki ani baletki).

Czy wypowiadający albo piszący je profesorowie mają wewnętrzne przekonanie, że obrazują w ten emocjonalny sposób prawdę? Tego nie wiem. Czy zastosowali procedury poznawcze, $\mathrm{z}$ ich skomplikowaną technologią intelektualną, którym można zaufać? Oczywiście nie.

Możliwe, że naukowcy w taki, prezentowany w mediach, obraz świata prawa i polityki sami wierzą, a ponieważ wiedzą też, że media żywią się socjomagią, ich celem jest ostentacyjne wsparcie albo osłabienie w tych wypowiedziach legitymizacji władzy politycznej, świadome wkroczenie w subiektywny świat ideologii.

Ideologie są jednym z podstawowych źródeł budowy legitymacji władzy państwowej, rozumianej jako stworzenie u obywateli przekonania, że ci, którzy rządzą, są do tego uprawnieni, a sposoby sprawowania władzy są prawowite albo odwrotnie: zmierzają do promowania wizji innego systemu politycznego niż panujący. Ideologia stymuluje zsubiektywizowane postrzeganie rzeczywistości zgodnie z przyjętym systemem wartości, Prawnik-ideolog nie zachowuje lojalności wobec norm metodologii i etyki badań naukowych. Nakreśla optymalny obraz określonej sfery zjawisk społecznych, często wytyczając także drogi prowadzące do jego urzeczywistnienia.

Nasycenie nauk prawnych ideologią przez wieki było i nadal jest faktem; jest też permanentnym zagrożeniem fundamentalnych wartości poznawczych wiedzy, zwłaszcza jeśli tezy naukowe i oświadczenia propagandowe tworzą wymieszany zbiór wypowiedzi o trudnych do wyznaczenia granicach między nimi. Manipulowanie wiedzą i propagandą jest typowe dla mediów. Jest też efektem wpływu innych czynników na działania naukowców. Jeden z nich uznaję obecnie za szczególnie ważny, chodzi o postmodernistyczną wiarę w zalety post-dysyplinarności 
i jej skutki ${ }^{22}$. Post-dyscyplinarność to wciąż modna w Polsce postawa niechęci do zintegrowanych stanowisk w naukach prawnych i do ogólnych teorii (np. teorii wykładni prawa, polityki prawa, teorii tworzenia prawa), niechęć do spójnych wymagań metodologii, do logiki i warsztatu specyficznych prawniczych rozumowań. To niechęć do studiowania filozofii prawa, historii prawa, do wiedzy ogólnej z zakresu ekonomii, socjologii i psychologii. W konsekwencji tego podejścia prawnik-naukowiec pozbawiony jest intelektualnej tkanki stanowiącej głębokie tło jego rozumowań, nie ma wiedzy metodologicznej, nie rozumie zasad i kodów kulturowych. Stopniowo dochodzi też w ten sposób do coraz silniejszej izolacji i autonomizacji kodów i języków poszczególnych nauk dogmatyczno-prawnych oraz głębokiej separacji ich od innych nauk (ekonomii, socjologii, psychologii, językoznawstwa, filozofii itd.).

Wewnętrzna fragmentaryzacja myślenia o prawie jest korzystna dla tych sił politycznych, które chcą manipulować grupą zawodową prawników. Prowadzi do promowania naukowców-,,specjalistów jednej ustawy”, głęboko odseparowanych od innych i uważających, że właśnie taka izolacja jest właściwa, bo gwarantuje im status ekspertów. Ale taka postawa przyniosła też za sobą aprobatę dla programowego „zapominania” o możliwych systematyzacjach, o zasadach, o wartościach wewnętrznych prawa w Fullerowskim rozumieniu i o aksjologii zewnętrznej prawa, np. sprawiedliwości, bezpieczeństwie, praworządności. W ten sposób w środowisku samych prawników tworzy się, niestety, naturalny klimat do szerzenia się mitów i stereotypów prawnych. Jeśli naukowiec zajmujący się prawem, ulegając tej modzie, zajmuje się wyłącznie wysoce specjalistycznym zakresem spraw, nie uznaje za ważne, aby studiować stale także filozofię czy ekonomię, porusza się w intelektualnej mgle, w filozoficznej próżni, łatwo sam ulega złudzeniom i magii zdroworozsądkowego myślenia. Atomizacja, separacja, fragmentaryzacja nauk prawnych jest więc poważnym, narastającym problemem stwarzającym zagrożenia niezależności prawników ${ }^{23}$.

Może być również tak, że prawnicy-naukowcy mają wiedzę o sposobach działania mediów i wobec tego świadomie wykorzystują je nie tylko w celach promowania swojej wiedzy eksperckiej, lecz przekonywania do określonej ide-

22 Zaznaczam, że przytoczonych przykładów wypowiedzi nie łączę z ideą postdyscyplinarności. Idea ta stanowi ewentualnie problem dla pokolenia prawników młodszego niż cytowani profesorowie.

23 „Alienacja prawa jest przejawem szerszego zjawiska ponowoczesnych społeczeństw, które można określić mianem komplikowania się systemów eksperckich. Prawniczy fach, podzielając w tym zakresie losy innych profesji, wymaga coraz większej specjalizacji, zaś reguły, wedle których działa prawnik, są coraz trudniej dostępne i zrozumiałe dla nieprofesjonalisty. Powstaje zatem problem napięcia między ekspansją prawa a jego hermetyzacją. $\mathrm{W}$ ścisłym związku z alienacją prawa pozostaje ewolucja jego charakteru, polegająca na ukształtowaniu się pozatekstowej, wypracowanej i przechowywanej przez prawników warstwy porządku prawnego". P. Jabłoński, P. Kaczmarek, O trzech granicach wtadzy prawniczej, „Archiwum Filozofii Prawa i Filozofii Społecznej” 2013, nr 1, s. 94. 
ologii, uznają bowiem, że wiedzą lepiej, jak powinien działać system polityczny, gospodarczy oraz społeczny i chcieliby mieć nań istotny wpływ. Wiedzą też, że operowanie chwytami erystycznymi, mitami, stereotypami, uprzedzaniami nie przystoi im w tekście naukowym, należy natomiast do zwykłych — czyli dopuszczalnych — środków propagandy medialnej ${ }^{24}$.

Prawnicy-naukowcy w komunikacji z opinią publiczną wykorzystują np. zdania mentalne. Mają one podstawy w sądach metajęzykowych, że są to zdania prawdziwe. Zdanie mentalne może być uważane za prawdziwe $m$.in. na podstawie wiary w jakiś autorytet, np. autorytet prawnika-sędziego Sądu Najwyższego czy profesora dobrej uczelni. „Podstawą dokonanej przez podmiot prawdziwościowej kwalifikacji danego zdania jest wiara w kompetencje innej osoby w danym zakresie, połączona $\mathrm{z}$ informacją, że ta kompetentna osoba uważa to zdanie za prawdziwe"25. Naukowcy wiedzą, że opinia publiczna może je uznać za prawdziwe, nawet jeśli nie rozumie, co one stwierdzają. Sędzia-profesor albo ambasador-profesor może na ogół wypowiadać się publicznie na dowolny temat, a „efekt aureoli” będzie działał. Naukowcy mają świadomość, że opinię publiczną kształtuje potoczna, a nie profesjonalna wiedza. Nie mamy tu do czynienia z uznawaniem kognitywnym, zdania nie są samodzielnymi sądami podmiotu, to wiara prowadzi do mentalnego uznawania zdań.

Uznawanie mentalne zdań odpowiada naturalnej tendencji ludzi do organizowania ich wyobrażeń o złożonej rzeczywistości prawnej, tendencji do generalizacji i ekonomizacji procesów poznawczych. Można więc w ten sposób utrwalić społeczne poparcie dla określonych poglądów, wspomóc władzę albo opozycję.

Można postawić hipotezę, że celem takiej propagandy jest kreacja określonej wizji rzeczywistości prawnej, politycznej, gospodarczej, społecznej — „reżyseria całościowa” obrazu określonego zjawiska i co za tym idzie — próba „immunizowania" zbiorowości na inne spojrzenia na fakty.

Przypuszczam, że naukowcy, formułując takie wypowiedzi, często świadomie działają jako ideolodzy i zacierają granice między różnymi aktami komunikowania, zwłaszcza tymi, które komunikują elementy poznawcze i tymi, które odnoszą się do stanów emocjonalnych. Takie cele ma np. renominacja zjawisk, podmiotów i przedmiotów przez tworzenie pozytywnych i negatywnych skojarzeń w mediach ${ }^{26}$. Czy naukowcy występujący w ten sposób w mediach chcą być postrzegani jako ideologiczni kreatorzy rzeczywistości? Czy robią to celowo? Jeśli mają elementarną samoświadomość metodologiczną — a zapewne mają i nie pozostają w filozoficznej próżni, odpowiedź brzmi - tak. Świadomie biorą udział w politycznej grze o władzę. Wiedzą, że w demokratycznym systemie poli-

24 To, moim zdaniem, powód wypowiedzi politycznych profesorów.

25 W. Patryas, Uznawanie zdań, Warszawa 1987, s. 151.

26 H. Marcuse, Człowiek jednowymiarowy, badania nad ideologiami rozwiniętego społeczeństwa przemystowego, Warszawa 1991, s. 164. 
tycznym władza polityczna jest zainteresowana przychylnością opinii publicznej, a opozycja — krytycznym stosunkiem opinii do władzy.

Drugim czynnikiem zewnętrznym utrudniającym zachowanie naukowej niezależności prawnikom-naukowcom i wikłającym ich niekiedy w polityczną grę jest „dwuetatowość”, czyli praca naukowa i równoległa praca w wymiarze sprawiedliwości, aparacie administracji państwa lub w organach przedstawicielskich, nie mówiąc już o pracy w aparacie partii politycznych czy wielkim biznesie. W tym wypadku problem etyczny i metodologiczny stwarza „efekt uczestnictwa”.

Naukowcy oddają swoje profesjonalne usługi organom państwa, urzędom, firmom prywatnym. Są wobec tego w ramach wykonywanej pracy podporządkowani służbowo i organizacyjnie tym instytucjom, ich standardom, audytom, normom i kontrolom. Traktują pracę zawodową wykonywaną poza nauką jako coś co pozwala zarobić na życie, jako zajęcie, któremu człowiek oddaje się między dziewiątą a siedemnastą, jednym okiem spoglądając na zegarek, a drugim kontrolując, czy zachowuje się odpowiednio profesjonalnie, tzn. nie wychyla się, nie wykracza poza akceptowane schematy lub granice, potrafi się sprzedać i jest reprezentacyjny, czyli niekontrowersyjny, apolityczny i „obiektywny”27.

Jako tzw. profesjonaliści nie są więc w pełni autonomiczni, „działania takie jak krytyka panującego status quo, występowanie w roli sumienia społeczeństwa, dążenie do prawdy bez względu na konsekwencje nie należą do repertuaru zachowań przydatnych w pracy profesjonalisty" 28 zatrudnionego na etacie.

Czy „efekt uczestnictwa”, praca na rzecz wymiaru sprawiedliwości, aparatu państwa, prywatnego biznesu albo na rzecz opozycyjnej czy rządzącej partii to atut, który powinien wyznaczać naukowcowi etycznie i metodologicznie dostępne pola badawcze, rzutować na wybierane albo odrzucane tematy i problemy badań? Czy w naukach prawnych „,badania wykorzystujące okoliczności” uczestnictwa są dopuszczalne? Pod jakimi warunkami metodologicznymi i etycznymi?

Jeśli zgodzimy się, że w naukach prawnych bada się wypowiedzi językowe i działające układy społeczne (np. dialog sądów europejskich, działanie UE, relacje posłów z wyborcami, organizację opieki społecznej, związki organizacji sportowych i ministerstwa sportu, działanie giełdy itd.), to trzeba też się zgodzić, że punktem wyjścia do podjęcia metodologicznie poprawnych badań, zarówno analitycznych, jaki i syntetycznych, jest ustalenie, jaką postawę powinien zająć naukowiec w stosunku do obiektu swoich badań.

Po pierwsze, można przyjąć, że powinien pozostać „obcym” w stosunku do obiektu, „zrzucić z siebie obszerny kostium nieświadomych założeń kulturowych, praktycznych zasad, typów wrażliwości oraz - jak by to było możliwe - język, złożony z „,ram poznawczych”, a przyświecać mu powinno „pragnienie ucieczki

27 Może też być, i bywa, odwrotnie: nauka jest traktowana jak źródło zarobków, a pasję zaspakajają oni w pracy sędziego, adwokata czy posła. E. Said, Representation of the Intellectual, London 1994, s. 12, cyt. za: F. Furedi, Gdzie się podziali wszyscy intelektualiści?, Warszawa 2008, s. 45.

${ }^{28}$ F. Furedi, op. cit. 
oraz pozostania całkowicie na zewnątrz ontologicznych ram społecznych badanych obiektów". Po drugie, można uznać, że odwrotnie, jego celem powinno być wykorzystanie ,bycia uczestnikiem”, maksymalne zredukowanie dystansu, dostanie się do wnętrza układu, ,pragnienie głębszego zanurzenia się w rzeczywistości po to, aby specyficzne subiektywne procesy grupowe mogły się bezpośrednio przed nim ujawnić z całą swoją siłą"29. Obie postawy mają swoich obrońców i krytyków wśród metodologów badań społecznych.

Wydawałoby się, że wrażliwym badaczom w naukach prawnych powinno towarzyszyć stałe napięcie metodologiczne i etyczne: czy wybierać takie tematy i problemy badań, które pozwolą zachować dystans, aby możliwe było przeprowadzenie intersubiektywnie kontrolowalnych, niezależnych badań zjawisk prawnych; czy też należy właśnie wykorzystywać zawodową sytuację i jako „uczestnik” „poddać” się” układowi, aby uzyskać dostęp, zrozumienie, gruntownie poznać niuanse sytuacji, nie dać się wprowadzić w błąd przez informatorów? Chodzi o ustalenie, czy i pod jakimi warunkami badanie wytworów własnej instytucji jest metodologicznie poprawne i etyczne.

Jednak prawnicy-naukowcy w Polsce prawdopodobnie nie uważają na ogół, że jest to poważny problem, ponieważ nie dzielą się refleksjami metodologicznymi na ten temat w swoich tekstach. Milcząc, uznają, jak się zdaje, że zabieranie głosu (podkreślam: chodzi o głos w roli naukowca, specjalisty) „z wnętrza” co jest bardzo częste - nie budzi wątpliwości metodologicznych i etycznych ${ }^{30}$. Widzą raczej zalety, jakie płyną z uczestnictwa: łatwiejszy dostęp do informacji, lepsze zrozumienie kontekstów, podtekstów i niuansów. Nie martwi ich brak niezależności badawczej, nie poświęcają temu zagadnieniu specjalnej uwagi.

Brak dystansu do przedmiotu i problematyki badań może być, przy określonych założeniach, w określonych okolicznościach i przy zastosowaniu specjalnych procedur metodologicznych zaletą, ale może być też bez wątpienia wadą. Trudno zachować neutralność i nie ulec aksjologii układu, czyli miejsca pracy zawodowej, trudno przyjąć postawę krytyczną, abstrahować od zasad, ram poznawczych i systemu wartości obowiązujących i aprobowanych w środowisku zawodowym, którego jest się ważnym elementem, chyba że zamierza się je szybko opuścić ${ }^{31}$.

Każde badanie jest oczywiście ukierunkowane przez żywione przez prawnika-naukowca głębokie przekonania dotyczące prawa i jego działania w systemie politycznym. Naukowiec powinien starać się je jasno wyartykułować w założeniach badań. Może to zrobić bez przeszkód, jeśli jest zawodowo autonomiczny. W trudniejszej sytuacji jest, jeśli ponadto pozostaje zanurzony w określonym

29 Cytaty z eseju Freda Davisa. Por. F. David, The Martian and the convert: Ontological polarities in social research, „Urban Life” 2, 1973, s. 336, 338, przekład S. Urbańska, [w:] J. Lofland, D.A. Snow, L. Anderson, Analiza układów społecznych. Przewodnik metodologiczny po badaniach jakościowych, przeł. A. Kordasiewicz, S. Urbańska, M. Żychlińska, Warszawa 2009.

30 Uważam, że warto ten problem zbadać, jest to jedynie hipoteza.

31 Np. sędzia Sądu Najwyższego pisze o orzecznictwie swojego sądu. 
układzie organizacyjnym (np. sędzia badający orzecznictwo sądu, w którym pracuje), ponieważ powinien stać ponadto na gruncie określonej oficjalnej ideologii czy pragmatyki służbowej, opierać się na firmowym systemie wartości, na zasadach etyki i zasadach zachowania tajemnicy zawodowej. Zastanawiać się może co najwyżej, w jakim zakresie ma sam zaprojektować lepsze rozwiązania ustawowe (formułując postulaty de lege lata i de lege ferenda) ${ }^{32}$.

Praca naukowa prawnika, który jest jednocześnie zatrudniony w innej roli zawodowej (sędzia, poseł, radca prawny, ambasador), jest więc często „badaniem wykorzystującym okoliczności”. Powstawać wówczas powinny pytania o to, jakie znaczenie dla wyników ma autonomia poznawcza i niezależność badawcza. W wypadku nakładania się ról (np. naukowca i sędziego albo naukowca i polityka albo dyplomaty) bez wątpienia tworzą się dodatkowe problemy etyczne i metodologiczne. Na przykład, czy prezes Sądu Najwyższego może (inaczej mówiąc: czy jest to poprawne metodologicznie i etycznie) obiektem swoich badań uczynić problem prawny, który ujawnił się w orzecznictwie jednej z izb tegoż sądu? Czy sędzia wizytator może pisać pracę naukową o wizytacjach? Możliwe są też konsekwencje osobiste (np. czy naruszyłem zasady etyki naukowej i zawodowej, bo „zdradziłem” tajemnice pracy kolegów, opisując jakieś ukryte dotąd jej aspekty?).

Za każdym projektem badawczym różnych aspektów prawa - językowych, socjologicznych, psychologicznych, statystycznych, ekonomicznych itd. — stoi osobista, zawodowa prawnicza, polityczna, dyplomatyczna, urzędnicza biografia badacza, który zabiera głos z punktu widzenia określonego miejsca, jakie zajmuje także w pozanaukowej strukturze zawodowej. Prowadzi swoje badania ze zbiorem pojęć, ram, które przyjął w ramach pracy w instytucji, wyznaczają one również zespół pytań, na które naukowiec szuka odpowiedzi. Należy do konkretnej interpretatywnej i etycznej pozanaukowej społeczności zawodowej, ona także kształtuje jego postrzeganie prawa (polityk, dyplomata, sędzia). Naukowiec ma więc problem jak Janus, rzymski bóg bram, domów i miast, który miał dwa oblicza; inaczej może wobec tego być postrzegany z zewnątrz i z wewnątrz: przez swój warsztat badacza oraz przez swoją środowiskową i zawodową biografię, bo obie konstytuują jego perspektywę badawczą i współtworzą mapę poznawczą. Ta złożona sytuacja wymaga dużej samoświadomości metodologicznej badacza i woli dążenia do prawdy bez względu na konsekwencje. Jego pozycja w naukach prawnych w konkretnym państwie jest więc wynikiem interakcji społecznych w dziedzinie władzy, w tym władzy mediów i sytuacji zawodowej, ,[...] jak zawsze w przypadku skomplikowanych interakcji społecznych, jednostki i grupy pracują, żeby zabezpieczyć własny interes [...]. Te warunki sprawiają, że proces

32 J. Jabłońska-Bonca, Auctoritas non veritas... Tam szerzej o funkcjach autorytetów prawniczych. 
określania kryteriów badawczych i sposobów ich wykorzystania jest bezdyskusyjnie sporny, a przez to polityczny"33.

\section{“THE EFFECT OF AUREOLE” AND "EFFECT OF PARTICIPATION” IN THE LIGHT OF INDEPENDENCE OF LAWYERS-SCIENTISTS}

\section{Summary}

The purpose of the text is to signal the need to investigate the conditions for the preservation of the independence of lawyers who practice and simultaneously engage in science. Research independence is understood in the text as loyalty to the principles of methodology and ethics of research. There have been, and will be, lawyers-scientists who are creative, well-skilled to do research, and also autonomous, capable of criticizing the status quo, striving for truth no matter what the consequences. In the 21 st century, being in such a position is getting harder and harder. This is due to the fact that many lawyers-scientists concurrently perform important social and occupational roles besides scientific research. The article focuses on two examples of conditions that hinder the preservation of independence and entice lawyers-scientists into the world of politics and ideology. It is: a) the activity of lawyers-scientists in the mass media and the consequences of the so-called "aureole effect", as well as b) the "dual occupancy" and the meaning of "participation effect".

33 J.K. Smith, P. Hodkinson, Relatywizm, kryteria i polityka, [w:] Metody badań jakościowych, t. 2, red. N.K. Denzin, Y.S. Lincoln, Warszawa 2009, s. 392. 